\title{
GAMBARAN TURNOVER INTENTION PADA KARYAWAN GENERASI Y DI PT. XYZ (IT SOLUTION COMPANY)
}

\author{
Aisyah N. Asih', Zamralita ${ }^{2}$ \\ ${ }^{1}$ Fakultas Psikologi, Universitas Tarumanagara Jakarta \\ Email: aish29ahmad@gmail.com \\ ${ }^{2}$ Fakultas Psikologi, Universitas Tarumanagara Jakarta \\ Email: zamralita@fpsi.untar.ac.id
}

\begin{abstract}
ABSTRAK
PT. XYZ merupakan perusahaan yang bergerak di bidang IT Solution yang memiliki 14 kantor cabang di seluruh Indonesia. Dengan pertumbuhan ekonomi PT. XYZ yang semakin meningkat, terdapat beberapa masalah yang cukup mengkhawatirkan dan membutuhkan perhatian khusus. Dalam tiga tahun terakhir, diketahui bahwa terjadi turnover yang terus meningkat di setiap tahunnya. Di mana dari data yang dikumpulkan menunjukkan bahwa turnover di PT. XYZ banyak terjadi pada karyawan dengan tingkat pendidikan S1 ke atas dan rentang usia 20-35 tahun dengan masa kerja yang berada dalam rentang satu sampai lima tahun. Hal ini tentu menjadi perhatian serius mengingat karyawan dalam rentang usia tersebut merupakan karyawan generasi Y yang diharapkan menjadi generasi penerus yang nantinya mampu membangun perusahaan menjadi lebih baik. Penelitian ini bertujuan untuk memeroleh gambaran turnover intention pada karyawan generasi Y di PT. XYZ. Metode yang digunakan dalam penelitian ini adalah kuantitaf non experimental dengan metode deskriptif. Sebanyak 114 responden yang tersebar di kota Medan, Palembang, Serang, Jakarta, Bogor, Bandung, Cirebon, Yogyakarta, Semarang, Solo, Surabaya, Malang, Denpasar, dan Makassar berpartisipasi dalam penelitian ini. Data diperoleh melalui kuesioner turnover intention scale yang diadaptasi dari Tet \& Mayer (1993) yaitu six item version of Turnover Intention Scale (TIS-6) yang berisi 10 butir pernyataan. Hasil penelitian menunjukkan bahwa tingkat pendidikan memiliki nilai yang pengaruh yang signifikan yaitu sebesar 0,000. Hal ini menggambarkan bahwa semakin tinggi tingkat pendidikan responden maka semakin tinggi turnover intention yang akan terjadi. Selain itu, departemen memiliki nilai yang signifikan yaitu sebesar 0,031. Hal ini menggambarkan departemen di PT. XYZ memiliki pengaruh yang signifikan terhadap turnover intention terutama pada pada departemen Internal Audit dan HRD yang menunjukkan adanya keinginan untuk berpindah pekerjaan yang tinggi.
\end{abstract}

Kata kunci: Turnover Intention, Generasi Y, IT Solution

\section{PENDAHULUAN Latar Belakang}

Turnover intention merupakan masalah klasik yang dihadapi hampir di setiap perusahaan. Keluarnya karyawan dari sebuah perusahaan dapat didasarkan oleh berbagai macam alasan. Perpindahan karyawan dari satu perusahaan ke perusahaan lain merupakan hal yang menjadi perhatian mengingat fenomena ini tidak hanya menjadi momok dalam perencanaan strategi bisnis dalam sebuah perusahaan, namun juga menjadi perhatian khusus dalam bidang rekrutmen dan talent management.

Generasi Y sebagai generasi yang kini mulai banyak memasuki perusahaan merupakan sumber daya manusia yang penting dan diharapkan mampu mengubah iklim suatu organisasi menjadi lebih produktif. Sebagai generasi yang tumbuh dengan perkemangan teknologi dan komunikasi yang cepat, generasi $\mathrm{Y}$ tentu memiliki karakteristik yang unik dan berbeda dengan karakteristik pada generasi-generasi sebelumnya, seperti generasi $\mathrm{X}$ dan baby boomers. Namun pada kenyataannya, generasi $\mathrm{Y}$ dinilai memiliki kecenderungan untuk mudah dalam berpindah pekerjaan. 
Myers (2010) mengungkapkan bahwa generasi Y berekspektasi pada kesuksesan namun juga menghargai fleksibilitas mereka dalam bekerja dimana terdapat keseimbangan antara bekerja dan bermain. Sheahan (2008) mengemukakan bahwa hasil survey menunjukkan bahwa karyawan generasi $\mathrm{Y}$ di wilayah Asia Pasifik memiliki masa kerja terpendek dibandingkan dengan karyawan pada generasi lainnya (generasi $X$ dan baby boomers). Karyawan pada generasi $Y$ memiliki rata-rata masa kerja selama 18 bulan, dibandingkan dengan karyawan pada generasi lainnya yang memiliki masa kerja rata-rata selama empat tahun.

Gen Y menginginkan keseimbangan kehidupan kerja dengan fleksibilitas untuk menentukan siapa mereka dalam pekerjaan mereka. Generasi Y menghadirkan tantangan bagi para manajer yang harus melatih dan memotivasi generasi penerus karyawan ini sehingga kekuatan mereka menjadi keuntungan bagi perusahaan. Mampu memahami generasi baru saat mereka masuk menjadi ke kelompok kerja baru dibutuhkan penyesuaian bagi para manajer selama bertahuntahun. Untuk mencapai kesuksesan di masa depan, penting bagi perusahaan dan manajer untuk memahami karyawan baru pada generasi Y ini (Meier, Austin, \& Crocker, 2010). Berdasarkan hal tersebut, peneliti ingin melihat gambaran turn over intention pada generasi Y di PT. XYZ.

\section{Telaah Pustaka}

Lacity, Lyer dan Rudramuniyaiah (2008) mendefinisikan turnover intention sebagai '... sejauh mana seorang karyawan berencana untuk meninggalkan organisasi'. Bester (2012) berpendapat bahwa banyak peneliti (Horn, Griffeth \& Salaro, 1984; Mobley, 1982; Mowday, Steers, \& Porter, 1979; Steers, 1977) memandang turnover intention sebagai langkah terakhir dalam proses pengambilan keputusan sebelum seseorang benar-benar meninggalkan tempat kerja. Sedangkan Tett dan Meyer (1993) mendefinisikan turnover intention sebagai berikut:

'... the conscious and deliberate wilfulness to leave the organisation'.

Arokiasami (2013) mengemukakan bahwa turnover intention dapat diklasifikasikan menjadi dua, yaitu turnover intention dengan kemauan sendiri (voluntary turnover) dan turnover intention bukan dengan kemauan sendiri (involuntary turnover).

Generasi Y atau yang biasa disebut dengan generasi Millenials. Meier, Austin, \& Crocker, (2010) dalam penelitiannya mengemukakan bahwa generasi Y secara luas dikenal sebagai generasi yang lahir antara tahun 1980 dan 2000. Generasi ini percaya diri, mandiri, dan berorientasi pada tujuan. Meskipun, kemajuan teknologi dimulai pada era Gen X, Generasi Y lahir dalam teknologi dan seringkali mengetahui lebih banyak tentang dunia digital daripada guru dan orang tua mereka. Pengetahuan teknologi yang disempurnakan telah meluncurkan generasi ini ke era yang dapat diakses di mana-mana bagi siapapun. Gen Y memiliki harga diri yang tinggi. Mereka adalah generasi piala yang memungkinkan setiap anak mendapat medali atau pujian, tidak meninggalkan siapa pun.

\section{METODE PENELITIAN}

Metode penelitian merupakan penelitian kuantitatif dengan data yang dikumpulkan didapat dari dari skor skala turnover intention. Teknik sampling yang digunakan merupakan teknik purposive (non probability sampling). Di mana peneliti menentukan kriteria dari responden yang akan digunakan. Sedangkan desain yang digunakan adalah convenience sampling, yaitu berdasarkan kesediaan partisipan untuk mengisi kuesioner (Graveter \& Forzano, 2009). 
Dalam pengumpulan data pada penelitian ini menggunakan kuesioner dan diberikan kepada responden yaitu karyawan PT. XYZ secara online atau melalui e-mail. Jumlah responden sejumlah 114 karyawan. Adapun kriteria dari responden penelitian adalah sebagai berikut: 1) Rentang usia partisipan adalah usia 20-37 tahun, dan; 2) telah bekerja di PT. XYZ minimal satu tahun.

Dalam penelitian ini digunakan adaptasi alat ukur dari Tet \& Meyer (1993) yaitu kuesioner six item version of Turnover Intention Scale (TIS-6) yang berisi 10 butir pernyataan dengan unidimensi. Skala pengukuran yang digunakan adalah skala Likert dimulai dari 1 (sangat tidak setuju) sampai 4 (sangat setuju). Uji realibilitas yang dilakukan memiliki nilai reliabilitas yang baik. Koefisien reliabilitas sebesar 0,885.

\section{HASIL DAN PEMBAHASAN}

\section{Gambaran Responden}

Penelitian ini dilakukan pada 114 karyawan generasi Y yang bekerja di PT. XYZ baik di kantor pusat yang terletak di Jakarta juga di 14 kantor cabang yang terletak di Medan, Palembang, Serang, Jakarta, Bogor, Bandung, Cirebon, Yogyakarta, Semarang, Solo, Surabaya, Malang, Denpasar, dan Makassar. Selanjutnya gambaran responden yang terdiri dari aspek jenis kelamin, usia, tingkat pendidikan, status kepegawaian, jabatan, range salary dan departemen yang dapat dilihat pada tabel 1 . 
Tabel 1. Gambaran Demografi Responden Penelitian

\begin{tabular}{|c|c|c|c|}
\hline & Aspek & Jumlah & Persentase \\
\hline \multirow[t]{3}{*}{ Jenis Kelamin } & Laki-laki & 57 & $50 \%$ \\
\hline & Perempuan & 57 & $50 \%$ \\
\hline & Total & 114 & $100 \%$ \\
\hline \multirow[t]{4}{*}{ Usia } & 20-25 tahun & 34 & $29,8 \%$ \\
\hline & 26-31 tahun & 49 & $43 \%$ \\
\hline & 31-37 tahun & 31 & $27,2 \%$ \\
\hline & Total & 114 & $100 \%$ \\
\hline \multirow[t]{5}{*}{ Tingkat Pendidikan } & SMA & 26 & $22,8 \%$ \\
\hline & Diploma & 21 & $18,4 \%$ \\
\hline & $\mathrm{S} 1$ & 66 & $57,9 \%$ \\
\hline & $\mathrm{S} 2$ & 1 & $0,9 \%$ \\
\hline & Total & 114 & $100 \%$ \\
\hline \multirow[t]{3}{*}{ Status Kepegawaian } & Kontrak & 104 & $91,2 \%$ \\
\hline & Tetap & 10 & $8,8 \%$ \\
\hline & Total & 114 & $100 \%$ \\
\hline \multirow[t]{5}{*}{ Jabatan } & Staff & 101 & $88,6 \%$ \\
\hline & Officer & 2 & $1,8 \%$ \\
\hline & Assistant Manager & 6 & $5,3 \%$ \\
\hline & Manager & 5 & $4,4 \%$ \\
\hline & Total & 114 & $100 \%$ \\
\hline \multirow[t]{3}{*}{ Range Salary } & Rp. 2.000.000 - Rp. 4.999 .999 & 102 & $89,5 \%$ \\
\hline & Rp. 5.000.000 - Rp. 9.999 .999 & 12 & $10,5 \%$ \\
\hline & Total & 114 & $100 \%$ \\
\hline \multirow[t]{9}{*}{ Departemen } & Internal Audit / Penjaminan Mutu & 1 & $0,9 \%$ \\
\hline & General Affair & 19 & $16,7 \%$ \\
\hline & $\begin{array}{c}\text { Company Relation / Social } \\
\text { Responsibility }\end{array}$ & 3 & $2,6 \%$ \\
\hline & HRD & 1 & $0,9 \%$ \\
\hline & Production & 2 & $1,8 \%$ \\
\hline & Finance & 18 & $15,8 \%$ \\
\hline & Information Technology & 34 & $29,8 \%$ \\
\hline & Marketing & 36 & $31,6 \%$ \\
\hline & Total & 114 & $100 \%$ \\
\hline
\end{tabular}

Dari tabel 1 dapat dilihat bahwa penelitian ini diikuti oleh 50\% responden laki-laki dan perempuan dengan persentase usia responden terbesar berada pada rentang usia 26-31 tahun 
yaitu sebesar $49 \%$. Mayoritas responden dari penelitian ini berada pada tingkat pendidikan S1 yaitu sebesar 57,9\% dengan status kepegawaian kontrak sebesar 91,2\% dan memiliki rentang salary Rp. 2.000 .000 - Rp. 4.999 .999 sebesar 89,5\%. Selain itu, mayoritas responden juga berasal dari level jabatan staff sebesar 88,6\% dan departemen marketing sebesar 31,6\%.

\section{Hasil Penelitian dan Analisa}

Dalam penelitian ini, untuk melihat gambaran turnover intention yang dikaitkan dengan demografi responden lainnya diambil dengan skala kuesioner (Skala 1-4) dengan menggunakan nilai rata-rata (mean) dan taraf signifikasi (sig. < 0.005). Adapun kategori yang digunakan adalah sebagai berikut: Rendah: skor rata-rata (mean) sebesar 1-1,337; Sedang: skor rata-rata (mean) sebesar 1,338-2,667, dan; Tinggi: skor rata-rata (mean) sebesar 2,668-4.

Berikut merupakan uraian gambaran turnover intention dari generasi Y di PT. XYZ seperti yang terlihat pada tabel 2.

Tabel 2. Gambaran Turnover Intention pada Generasi Y di PT. XYZ

\begin{tabular}{|c|c|c|c|c|}
\hline & Aspek & Mean & Kategori & Sig. $(<0.05)$ \\
\hline \multirow[t]{2}{*}{ Jenis Kelamin } & Laki-laki & 2,1735 & Sedang & 0,567 \\
\hline & Perempuan & 2,1520 & Sedang & \\
\hline \multirow[t]{3}{*}{ Usia } & 20-25 tahun & 1,9837 & Sedang & 0,069 \\
\hline & 26-31 tahun & 2,2766 & Sedang & \\
\hline & 31-37 tahun & 2,1792 & Sedang & \\
\hline \multirow[t]{4}{*}{ Tingkat Pendidikan } & SMA & 1,8974 & Sedang & 0,000 \\
\hline & Diploma & 1,9683 & Sedang & \\
\hline & S1 & 2,3098 & Sedang & \\
\hline & $\mathrm{S} 2$ & 3,4444 & Tinggi & \\
\hline \multirow[t]{2}{*}{ Status Kepegawaian } & Kontrak & 2,1357 & Sedang & 0,944 \\
\hline & Tetap & 2,4444 & Sedang & \\
\hline \multirow[t]{4}{*}{ Jabatan } & Staff & 2,1540 & Sedang & 0,384 \\
\hline & Officer & 2,7778 & Tinggi & \\
\hline & Assistant Manager & 2 & Sedang & \\
\hline & Manager & 2,2889 & Sedang & \\
\hline \multirow[t]{2}{*}{ Range Salary } & Rp. 2.000.000 - Rp. 4.999 .999 & 2,1242 & Sedang & 0,162 \\
\hline & Rp. 5.000.000 - Rp. 9.999 .999 & 2,4907 & Sedang & \\
\hline
\end{tabular}


Continued

\begin{tabular}{cccc}
\hline Aspek & Mean & Kategori & Sig. $(<\mathbf{0 . 0 5})$ \\
\hline $\begin{array}{c}\text { Internal Audit / Penjaminan } \\
\text { Mutu }\end{array}$ & & \\
Departemen & 3 & Tinggi & 0.031 \\
General Affair & 1,8772 & Sedang \\
Company Relation / Social & 1,6667 & Rendah \\
Responsibility & & Tinggi \\
HRD & 3,2222 & Sedang \\
Production & 2,2778 & Sedang \\
Finance & 2,1296 & Sedang \\
Information Technology & 2,3072 & Sedang \\
\hline Marketing & 2,1759 & \\
\hline
\end{tabular}

Berdasarkan data pada tabel 2, penelitian ini, untuk melihat gambaran turnover intention yang dikaitkan dengan demografi responden diambil dengan skala kuesioner (Skala 1-4) dengan menggunakan nilai rata-rata (mean) dan nilai sig. (sig. < 0.05). Adapun kategori yang digunakan adalah sebagai berikut: Rendah: skor rata-rata (mean) sebesar 1-1,337; Sedang: skor rata-rata (mean) sebesar 1,338-2,667, dan; Tinggi: skor rata-rata (mean) sebesar 2,668-4.

Pada jenis kelamin yang dikaitkan dengan turnover intention, baik laki-laki dan perempuan berada pada kategori sedang dengan nilai sig. sebesar 0,567. Hal ini menggambarkan jenis kelamin tidak memiliki pengaruh yang signifikan terhadap turnover intention. Baik laki-laki atau perempuan memiliki kecenderungan yang sama pada turnover intention. Begitu pula pada usia yang dikaitkan dengan turnover intention, di mana ketiga kelompok usia berada pada kategori sedang dengan nilai sig. sebesar 0,069. Hal ini menggambarkan bahwa usia tidak memiliki pengaruh yang signifikan terhadap turnover intention. Turnover intention dapat terjadi pada setiap rentang usia 20-25 tahun, 25-31 tahun, dan 32-37 tahun. Meski begitu terdapat nilai mean yang lebih besar pada rentang usia 25-31 tahun.

Pada tingkat pendidikan yang dikaitkan dengan turnover intention, terlihat bahwa responden dengan tingkat pendidikan SMA, Diploma dan S1 berada pada kategori sedang dan responden dengan tingkat pendidikan S2 berada pada kategori tinggi dengan nilai sig. sebesar 0,000. Hal ini menggambarkan bahwa semakin tinggi tingkat pendidikan responden maka semakin tinggi turnover intention yang akan terjadi. Hal itu terkait dengan luasnya kesempatan kerja, salary serta karir yang menjanjikan untuk mereka yang memiliki tingkat pendidikan yang lebih tinggi. Sedang mereka yang memiliki tingkat pendidikan yang lebih rendah cenderung bertahan pada pekerjaan yang dimiliki.

Pada aspek status kepegawaian yang dikaitkan dengan turnover intention, baik responden dengan status kepegawaian kontrak maupun tetap berada pada kategori sedang dengan nilai sig. sebesar 0,944. Hal ini menggambarkan status kepegawaian tidak memiliki pengaruh yang signifikan terhadap turnover intention. Baik responden dengan status kepegawaian kontrak 
maupun tetap memiliki kecenderungan yang sama pada turnover intention. Begitu pula pada aspek range salary yang dikaitkan dengan turnover intention, di mana kedua kelompok salary berada pada kategori sedang dengan nilai sig. sebesar 0,162 . Hal ini menggambarkan range salary tidak memiliki pengaruh yang signifikan terhadap turnover intention. Turnover intention dapat terjadi pada setiap aspek range salary baik mereka yang memiliki salary sebesar Rp. 2.000.000 - Rp. 4.999.999 ataupun Rp. 5.000.000 - Rp. 9.999.999.

Pada level jabatan yang dikaitkan dengan turnover intention, terlihat bahwa responden dengan level jabatan Staff, Assistant Manager dan Manager berada pada kategori sedang dan responden dengan level jabatan Officer berada pada kategori tinggi dengan nilai sig. sebesar 0,384. Hal ini menggambarkan bahwa level jabatan tidak berpengaruh secara signifikan terhadap turnover intention. Meski begitu terlihat nilai mean yang lebih besar pada level jabatan Officer.

Pada bagian departemen yang dikaitkan dengan turnover intention, selain departemen internal audit dan HRD yang memiliki kategori tinggi, keenam departemen lainnya berada pada kategori sedang dengan nilai sig. sebesar 0,031. Hal ini menggambarkan departemen di PT. XYZ memiliki pengaruh yang signifikan terhadap turnover intention. Terlihat dari nilai mean yang berada pada kategori tinggi pada departemen Internal Audit dan HRD yang menunjukkan adanya keinginan untuk berpindah pekerjaan yang cukup besar.

Selanjutnya, untuk melihat korelasi antara usia kerja dengan turnover intention dari generasi Y dapat dilihat pada tabel 3 sebagai berikut.

Tabel 3. Korelasi Usia Kerja dengan Turnover Intention pada Generasi Y di PT. XYZ

\begin{tabular}{cc}
\hline Aspek & Sig. (2-tailed) \\
\hline Usia Kerja & 0.152 \\
$\mathrm{~N}$ & 114 \\
\hline
\end{tabular}

Dari tabel 3 dapat dilihat bahwa korelasi antara usia kerja dengan turnover intention pada generasi Y di PT. XYZ memiliki nilai sig. sebesar 0,152. Hal ini menggambarkan bahwa usia kerja pada karyawan generasi Y di PT. XYZ tidak memiliki pengaruh yang signifikan terhadap turnover intention. Semua responden memiliki kecenderungan yang sama pada turnover intention.

\section{KESIMPULAN DAN SARAN}

\section{Kesimpulan}

Berdasarkan dari hasil penelitian ini menunjukkan bahwa dari 114 responden di PT. XYZ diketahui bahwa dari aspek-aspek demografi seperti aspek jenis kelamin, usia, tingkat pendidikan, status kepegawaian, jabatan, range salary, dan usia kerja diketahui bahwa tingkat pendidikan memiliki nilai yang signifikan yaitu sebesar 0,000. Hal ini menggambarkan bahwa semakin tinggi tingkat pendidikan responden maka semakin tinggi turnover intention yang akan terjadi. Selain itu, departemen memiliki nilai yang signifikan yaitu sebesar 0,031. Hal ini menggambarkan departemen di PT. XYZ memiliki pengaruh yang signifikan terhadap turnover intention terutama pada pada departemen Internal Audit dan HRD yang menunjukkan adanya keinginan untuk berpindah pekerjaan yang tinggi. 


\section{Saran}

Dengan semakin berkembangnya teknologi dan perubahan generasi yang mengisi posisi-posisi pekerjaan di perusahaan yang kini didominasi oleh generasi $\mathrm{Y}$ yang notabene mudah untuk berpindah pekerjaan, diharapkan perusahaan dan managerial memahami karakteristik generasi $\mathrm{Y}$ ini dan memiliki strategi-strategi khusus yang mampu membuat generasi $\mathrm{Y}$ bertahan di perusahaan dan mengembangkan dirinya dengan lebih maksimal. Hal itu penting mengingat generasi $\mathrm{Y}$ merupakan generasi penerus yang nantinya akan menjalankan perusahaan dan menjadi ujung tombak dari bisnis perusahaan.

\section{Ucapan Terima Kasih}

Peneliti mengucapkan terima kasih pada manajemen PT. XYZ yang telah memberikan ijin kepada peneliti untuk melakukan pengambilan data penelitian. Peneliti juga mengucapkan terima kasih dan apresiasi yang tinggi pada karyawan generasi Y di PT. XYZ yang telah bersedia meluangkan waktunya untuk mengisi kuesioner dan menjadi responden penelitian ini.

\section{REFERENSI}

Gravetter, F. J., \& Forzano, L. A. (2009). Research methods for the behavioral sciences (3rd ed.). Canada, CA: Wadsworth Cengage Learning.

Bester, F. (2012). A model of work identity in multicultural work settings. Unpublished DPhil thesis. Johannesburg: University of Johannesburg.

Bothma, C.F.C., \& Roodt, G. (2013). The validation of the turnover intention scale. SA Journal of Human Resource Management, 11(1), 1-12

Lacity, M.C., Lyer, V.V., \& Rudramuniyaiah, P.S. (2008). Turnover intentions of Indian IS professionals. Information Systems Frontiers on Outsourcing, 10, 225-241

Meier, J., Austin, Stephen F., \& Crocker, Mitchell. (2010). Generation Y in the workforce: Managerial challenges. The Journal of Human Resource and Adult Learning. 6 (1), 68-78

Myers, K. (2010). Millenials in the workplace: A communication perspective on millenials, organizational relationships and performance. Journal of Business and Psychology, 25, $225-238$

Sheahan, P., (2008). Generation-Y In Asia. Sydney: The University od Sydney.

Tet, Robert P., \& Meyer, John, P. (1993). Job satisfaction, organizational commitment, turnover intention, and turnover: Path analyses based on meta-analytic findings. Personel Psyhology, 46, 259-293

Treuren, G., \& Anderson, K. (2010). The employment expectations of different age cohorts: Is generation Y really different?. Australian Journal of Career Development, 19 (2). 